\title{
Challenges to modern methods of dispute resolution with respect to outer space activities
}

\author{
Desafios aos métodos modernos de resolução de disputas relativas \\ às atividades do espaço sideral
}

Evgeny Minchev ${ }^{1}$

\begin{abstract}
The purpose of this article is to identify the means of dispute settlement that are available to both states and private actors in cases relating to outer space commercial activities, as well as to show what each of these means has to offer to its potential users. In furtherance of this purpose, the article will analyze the challenges typically associated with different types of dispute settlement, such as mediation, arbitration and adjudication. In Part I, the author will present the questions and issues of interest regarding space activities' dispute resolution that will be examined in Parts II and III. Part II will deal with some of the venues before which parties to a dispute involving outer space activities may bring their cases and will try to identify key advantages and disadvantages posed by each of those methods. Finally, Part III will include some conclusory remarks, wherein the author will attempt to identify by virtue of comparison the best ways to resolve a dispute pertaining to outer space activities based on the status of the parties under international law and the remaining challenges to be tackled by the existing regime of dispute settlement.
\end{abstract}

Keywords: Dispute Settlement, Outer Space, Commercial Activities.

Resumo: O objetivo deste artigo é identificar os meios de solução de controvérsias disponíveis para Estados e atores privados nos casos relacionados a atividades comerciais do espaço sideral, além de mostrar o que cada um desses meios tem a oferecer aos seus usuários em potencial. Com este objetivo, o artigo analisará os desafios normalmente associados a diferentes tipos de solução de controvérsias, como mediação, arbitragem e adjudicação. Na Parte I, o autor apresentará as perguntas e questões relevantes relacionadas à resolução de disputas das atividades espaciais que serão examinadas nas Partes II e III. A Parte II tratará de alguns dos locais onde as partes de uma disputa envolvendo atividades no espaço sideral poderão apresentar seus casos e tentará identificar as principais vantagens e desvantagens apresentadas por cada uma dessa opções. Finalmente, a Parte III incluirá algumas observações conclusivas, nas quais o autor tentará identificar, comparativamente, as melhores maneiras de resolver uma disputa relacionada às atividades do espaço sideral com base no status das partes à luz do direito internacional e nos

\footnotetext{
${ }^{1}$ LLM in International Legal Studies with distinction from Georgetown University Law Center - United States. LLM in International Law and International Relations from Sofia Univeristy "St. Kliment Ohridski" - Bulgaria. Lawyer at Djingov, Gouginski, Kyutchukov \& Velichkov. Member of the Board of the International Moot Court Competition Association - IMCCA.
} 
desafios remanescentes a serem enfrentados pelo regime atual de solução de controvérsias.

Palavras-chave: Solução de controvérsias, Espaço sideral, Atividades Comerciais.

\section{An introduction to the topic of dispute settlement relating to space activities and some of the questions it raises}

A dispute has been defined by the PCIJ (1924, p. 11) as "a disagreement on a point of law or fact, a conflict of legal views or of interests between two persons" whereas the ICJ (1950, p. 74) has equated it to "a situation in which the two sides held clearly opposite views concerning the question of the performance or non-performance of certain treaty obligations". The author of this article lends preference to the former definition, with the necessary clarification however that persons should of course be interpreted as parties, thereby including not only natural but legal persons, states, inter-governmental organizations, non-governmental organizations, etc. [A settlement of a dispute is much more than simply 'declaring a winner', but also showing which party's view on the facts and the law prevails and the reasons thereof. That being said, an effective and appealing dispute resolution system is one which is accessible to as many stakeholders as possible, providing a fair, equitable, timely and costeffective resolution and very importantly, as will be later examined in this article, ensuring the recognition, enforcement and execution of the final decision (HERTZFELD; NELSON, 2011, p. 2).

In the context of outer space activities, a dispute could potentially involve a plethora of situations, which may however be grouped in several scenarios - an accident or occurrence taking place in space, an accident or occurrence that took place in space but led to the manifestation of certain results on Earth, most commonly space objects causing damage to private persons or property, and a third category wherein an activity or occurrence taking place on Earth is inextricably linked to an outer space activity (TRONCHETTI, 2013, p. 2). 
Throughout the article, an attempt will be made to address a nonexhaustive list of questions and challenges to dispute resolution in space law, in light of existing, as well as proposed models for dispute settlement. One of the fundamental questions relates to whether the current legal framework for settlement of disputes relating to outer space can be deemed as satisfactory and if not, what changes need to be introduced on the international and national level. Further to that point and more specifically a question arises as to whether the dispute resolution framework of today adequately addresses specific types of disputes, such as private entities versus states. If that is not the case, should this state of affairs be remedied as soon as possible or will that happen naturally as the importance of the space sector grows even more? 2

The 1984 ILA Draft Convention on Settlement of Outer Space Disputes [hereinafter ILA Draft Convention] which under its Article 37 establishes the International Tribunal for Space Law poses another question - is it really necessary at present to establish a permanent court or tribunal devoted exclusively to space disputes, when the demand, as some authors put it, is rather low? (HERTZFELD; NELSON, 2011, p. 9-10) There seems to be a considerable support in academia in favor of such a sectorialized approach to dispute settlement for space-related activities (POCAR, 2012, p. 174).

In this regard, it seems pertinent to also examine whether the tendency of states favoring non-binding methods of Alternative Dispute Resolution [hereinafter ADR], such as negotiations (GOH, 2007), is necessarily a worrying trend that needs to be rectified. As a penultimate point, how do cross-waivers of liability and the liability regime established under Convention on International Liability for Damage Caused by Space Objects [hereinafter Liability Convention] affect dispute settlement in space-related matters?

\footnotetext{
2 But see CHENG, 2001.
} 
Finally, this article asks the ultimate question - can we point to one form of dispute settlement, whether already in place or still contemplated, which is truly the best-suited for outer space activities? From the outset, the author of this article considers that the complexities entailed by outer space disputes presuppose a rather skeptical stance towards a 'one-size-fits-all' solution and instead opts for a careful weighing of the pros and cons that different methods have to offer to their users.

Turning to some of the challenges facing settlement of outer space disputes, one of the main issues is with respect to the restrictions upon users many of the methods impose. To be precise, various venues capable of resolving disputes concerning space law are not open to private entities, but only to states. ${ }^{3}$ Another issue which arises out of the difference in status under international law between private entities and states is one of recognition, enforcement and particularly execution of foreign arbitral awards.

As of 24 June 2018, the 1958 Convention on the Recognition and Enforcement of Foreign Arbitral Awards [hereinafter the New York Convention] will enter into force for its 159 th and newest member, Sudan (NEW YORK CONVENTION GUIDE, w/d). Such a widespread adoption of the convention in practice means that even if all signatories decide to recognize and enforce foreign arbitral awards on the basis of reciprocity under Article 1(3), that still equates to almost universal application of the rule.

Another relevant international instrument to be considered in this regard is the Convention on the Settlement of Investment Disputes between States and Nationals of Other States [hereinafter ICSID Convention], which has 162 signatories up to the present (ICSID, w/d). What is common here is that both conventions stipulate that recognition and enforcement may be sought against states as well (SAUNDERS; SALOMON, 2007, p. 469). The

\footnotetext{
${ }^{3}$ E.g., Statute of the International Court of Justice, art. 34(1).
} 
problems however arise not necessarily with recognition, nor even enforcement, but the execution of the arbitral award.

The New York Convention does not even mention the term, ${ }^{4}$ whereas the ICSID Convention does mention it, but subjects it to the legislation of the state against whose assets execution is sought (ICSID Convention, 1965, art. 54[3]). Execution against property of a state usually clashes with the sovereign immunity it enjoys, which prevails under international law, as some ICSID cases illustrate all too well. In AIG Capital Partners Inc. and another $v$. Republic of Kazakhstan and others it was held that Kazakhstan acted arbitrarily and in utter disregard of due process of land, its actions amounting to expropriation. Subsequently claimants tried to enforce the award in English courts against assets of the National Bank of Kazakhstan, but the English High Court refused recognition on the grounds that enforcement may only be directed against state property intended for commercial purposes, whereas the assets of a state's central bank are not considered to fall into that category (SAUNDERS; SALOMON, 2007, p. 469 et seq).

In LETCO v. Liberia, enforcement of an ICSID award against Liberia was granted, but the U.S. court refused execution against fees and taxes payable by shipowners in the United States to Liberia, since the collection of taxes by the Government of Liberia was an exercise of a sovereign power, and not a 'commercial activity' within the exception provided for in section 1610(a) of the FSIA (SAUNDERS; SALOMON, 2007, p. 469 et seq). In an attempt to address this issue, ICSID recommends the following model clause for the purpose of overcoming the sovereign immunity defense:

The Host State hereby waives any right of sovereign immunity as to it and its property in respect of the enforcement and execution of

\footnotetext{
${ }^{4}$ Except in Article 7(2) to stipulate that "the Geneva Convention on the Execution of Foreign Arbitral Awards of 1927 shall cease to have effect between Contracting States on their becoming bound and to the extent that they become bound, by this Convention" which bears no relevance in the present discussion.
} 
any award rendered by an Arbitral Tribunal constituted pursuant to this Agreement (ICSID Model Clauses, 1993).

Another barrage of challenges comes from the nature of the subject matter of outer space disputes - on one hand vital interests of national security present challenges to any proceedings that require the producing of evidence and on the other the technical character and specificity impose a high threshold for arbitrators, judges and mediators to meet in order to comply with the expectations of the users of the corresponding method of dispute settlement (BRISIBE, 2013, p. 14-15).

2. Types of dispute settlement for outer space activities and the benefits and shortcomings they entail.

\subsection{Dispute settlement mechanisms open exclusively to states.}

Article 33 of the Charter of the United Nations [hereinafter the UN Charter] provides that states shall primarily seek a solution of their disputes by "negotiation, enquiry, mediation, conciliation, arbitration, judicial settlement, resort to regional agencies or arrangements, or other peaceful means of their own choice". Further, it is established that the provisions of the UN Charter are applicable to activities in outer space. ${ }^{5}$

I will address in turn (2.1.1) dispute settlement under the Treaty on Principles Governing the Activities of States in the Exploration and Use of Outer Space, including the Moon and Other Celestial Bodies [hereinafter Outer Space Treaty] and the Convention on International Liability for Damage Caused by Space Objects [hereinafter Liability Convention], (2.1.2) adjudication by the International Court of Justice [hereinafter the ICJ],

\footnotetext{
${ }^{5}$ See G.A. Res. 1721 (XVI) A (International Co-operation in the Peaceful Uses of Outer Space); G.A. Res. 1802 Preamble (XVII) (International Co-operation in the Peaceful Uses of Outer Space); G.A. Res. 1962 (XVIII) (Declaration of Legal Principles Governing the Activities of States in the Exploration and Use of Outer Space); See also Treaty on Principles Governing the Activities of States in the Exploration and Use of Outer Space, including the Moon and Other Celestial Bodies [Outer Space Treaty], art. 3, 18 U.S.T 2410 (1967).
} 
(2.1.3.) dispute settlement by the International Telecommunication Union [hereinafter ITU] and (2.1.4.) dispute settlement under the World Trade Organization [hereinafter WTO]. A fifth example is provided, which is a type of non-binding settlement mechanism, i.e. (2.1.5.) NASA's bilateral legal framework agreements with other states' space agencies.

\subsubsection{Dispute settlement under the Outer Space Treaty and the Liability Convention}

At the outset it should be noted that the word arbitration or any variation thereof is not mentioned a single time in any of the five international law treaties on space law. The Outer Space Treaty mentions consultations in Articles 9 and 12, but rather than a dispute resolution mechanism, they are designed as steps in a process to avoid the occurrence of a dispute in the first place. This is so, as Article 9 calls for consultations before a state may undertake an activity that could "cause potentially harmful interference". Article 12 speaks in similar terms about taking precautionary measures.

By contrast, the Liability Convention addresses in Article 8 to 22 a dispute resolution mechanism, which is heavily influenced as will be shown, by the liability regime chosen. Article 5 of the Liability Convention provides that all states launching a space object together are jointly and severally liable for any damage caused by it. The dispute resolution mechanism under the Liability Convention would seem to be impractical especially as regards cases of the increasingly common nowadays joint space ventures, which involve joint and several liability for the launching states under Article 5. This is so as it would be "unfeasible for a launching state to declare acceptance of the compulsory nature of the Claims Commission if the other launching states do not do the same" (VIIKARI, 2011, p. 226).

As for the specifics of the dispute resolution under the Liability Convention, the injured state may present a claim against the launching 
state of the object that caused damage both in pursuing its own rights under international law and by exercising diplomatic protection. Both the territoriality and nationality principles apply when determining standing under Article 8 of the Liability Convention. Claims must be presented to the liable launching state(s) through diplomatic channels within one year of the date on which the damage occurred (LIABILITY CONVENTION, 1976, art. 10[1]) or within one year following the date when the state suffering damage learned or could reasonably be expected to have learned of the occurrence of the damage or the identity of the liable launching state LIABILITY CONVENTION, 1976, art. 10[2]).

After claims are presented, another one-year time limit applies for reaching a settlement and if none is achieved, the parties must, at the request of either of them, establish a Claims Commission LIABILITY CONVENTION, 1976, art. 14). The Claims Commission will be made up of one member chosen by each state party to the dispute and a chairman chosen jointly by them LIABILITY CONVENTION, 1976, art. 15[1]). This dispute resolution tool has been described by some authors as either an ad hoc tribunal (BÖCKSTIEGEL, 1993, p. 3) or a semi-arbitration court (SUPANCANA, 1998, p. 187).

This regime has been criticized (VIIKARI, 2011, p. 229; BURKE, 1984, p. 263; FOSTER, 1972, p. 175) for several reasons, such as the nonbinding character of the final decision, unless parties to the dispute have agreed otherwise under Article 19(2) of the Liability Convention. However, even if the Commission renders a "final and recommendatory award" (LIABILITY CONVENTION, 1976. art. 19[2]) instead, this award must still be considered in good faith under the same provision and thus states will be extremely reluctant to derogate from it (KERREST, 2001, p. 465-466).

One advantage of this regime is that it does not require exhaustion of local remedies when a state presents a claim to a launching state in the exercise of diplomatic protection of its nationals (LIABILITY 
CONVENTION, 1976. art. 11[1]). However, this brings with itself a drawback in that if a national of a state pursues his rights in the courts of a launching state, no concurrent claim against the launching state may be pursued by the state of the injured national under the Liability Convention.

Another disadvantage of this regime relates to the customary discretional powers of the state exercising diplomatic protection regarding whether or not to press and sustain the claim (ICJ, 1970, p. 44; LEYS, 2016, p. 7; GOROVE, 1980, p. 44), as well as whether and to what extent the compensation obtained is to be disbursed to the injured national (ILC, 2006, p. 97 - para. 5).

To conclude, two more disadvantages need to be pointed out. One relates to the potential for lengthy proceedings and uncertainty as to the enforceability of the decisions, especially if the parties did not agree on the binding effect of the Commission's decision. Another is the evaluation provided by history - in the more than 45 years that passed since its entry into force, the Liability Convention's dispute resolution mechanism has only been invoked once by Canada in the Cosmos 954 case, where Canada pressed a claim against the USSR under the Liability Convention. Ultimately, however, the matter was resolved under a protocol by which the Soviet Union agreed to pay a compensation in the amount of 3 million Canadian dollars "in full and final settlement of all matters connected with the disintegration of the Soviet satellite Cosmos 954 in January 1978", whereby the protocol did not refer to the Liability Convention (VIIKARI, 2011, p. 230).

\subsubsection{Adjudication by the International Court of Justice}

The main disadvantage here is that the ICJ is only open to states pursuant to Article 34(1) of its Statute. Some of the advantages include the fact that the ICJ is a permanent judicial body, thus obviating the need to be reconstituted for each case as in arbitration or other forms of alternative 
dispute resolution [hereinafter $\mathrm{ADR}$ ], as well as the competence and authority of the ICJ judges who are usually among the most eminent scholars in the field of public international law and that by art. 2 of the ICJ Statute are "jurisconsults of recognized competence in international law". By the present day there is also a substantial body of both ICJ and PCIJ cases $^{6}$ which sheds clarity as to the applicable norms of international law and the legal reasoning employed by the World Court.

Despite all these advantages however, the ICJ has not yet heard a single case concerning outer space activities (HOFMANN, 2014, p. 1). A numerical study by Arthad Kurlekar may provide at least a partial explanation as to this phenomenon. According to the study only 23 states parties to the Outer Space Treaty and 23 states parties to Liability Convention 7 may invoke the jurisdiction of the Court on conditions of reciprocity, thus reducing even more the potential usefulness of the Court (KURLEKAR, 2016, p. 389).

One way to increase the appeal of the ICJ is to create a special chamber of the ICJ for space law disputes under Article 26 of the ICJ Statute, similar to the formation of the ICJ Chamber for Environmental Matters. It should be noted, however, that the Environmental Chamber ceased to exist in 2006 and in the 13 years of its operation no state ever referred a case to it (ICJ, w/d) thus seriously undermining the chances of success of a similar venture.

\subsubsection{ITU regime of dispute settlement}

Another type of dispute settlement in matters pertaining to outer space activities is the one contained in the ITU Constitution and ITU Convention. The former under Article 56(1) gives a wide latitude to states to resort to negotiations or any other method agreed upon, whereupon if the

\footnotetext{
${ }^{6}$ Equally authoritative to ICJ cases under Article 38(1)(d) of the ICJ Statute

${ }^{7}$ Note that these are not the same 23 states.
} 
dispute remains unresolved, either of the states parties may have recourse to arbitration, which is regulated in detail within the ITU Convention. At first glance, this seems like a good solution as it provides the users of dispute resolution with many choices.

However, as some authors point out, this dispute resolution system has become a "dead letter" (VIIKARI, 2011, p. 231). All of this, combined with only allowing states to be parties to a dispute and the narrow selection of subject matters covered by ITU arbitration, such as harmful interference to registered radio frequencies (POCAR, 2012, p. 176) limit the usefulness of the regime for all outer space activities stakeholders.

\subsubsection{World trade organization dispute settlement}

According to the WTO website, a dispute arises when "a member government believes another member government is violating an agreement or a commitment that it has made in the WTO" (WTO, w/d). The dispute settlement mechanism of WTO is based on the provisions of the WTO Understanding on Rules and Procedures Governing the Settlement of Disputes [hereinafter WTO DSU Rules]. The dispute resolution mechanism under the WTO DSU Rules involves a mix of in-court and out-of-court methods, such as a review by panel, which may be appealed, consultations as between the parties all throughout the contentious proceedings, etc.

Contentious proceedings are carried out before panels, which under Article 8 of the WTO DSU Rules "shall be composed of well-qualified governmental and/or non-governmental individuals, including persons who have served on or presented a case to a panel". An interesting solution is the addition of Article 10, which stipulates that "the interests of the parties to a dispute and those of other Members under a covered agreement at issue in the dispute shall be fully taken into account during the panel process", an approach far more liberal than most arbitration rules would allow by virtue of comparison and thus worthy of praise. 
As of today, there are arguably only two cases that were ever presented before a WTO panel and have bearing on outer space activities at the same time. The first one was instituted at the request of the U.S. against Mexico due to alleged breach of obligations affecting telecommunication services and the second one involved a dispute between the European Union and Japan regarding the "procurement of a purchase of a multi-functional satellite for Air Traffic Management". It must be noted, however, that the latter case was resolved amicably (HOFMANN, 2014, p. 2).

\subsubsection{Bilateral legal framework agreements of NASA with foreign space agencies}

Another interesting example of an inter-state dispute resolution system is contained in the multitude of bilateral agreements between NASA and foreign space agencies for collaboration in the exploration of outer space. Indeed, NASA has concluded various bilateral legal framework agreements with the space agencies of other countries, which invariably contain an express provision for mandatory resolution of disputes through negotiations and consultations, whereby it is intended for those disputes to be resolved "at the lowest possible technical level" involving program managers and only in extremely rare cases reaching the level of NASA Administrator (WHOLLEY; MIRMINA, 2008, p. 7). Ironically, it would seem that by way of comparison, this system is much more successful than the preceding 3 combined.

From a different perspective, this example is illustrative in one more respect, i.e. the inclusion of cross-waivers of liability, which are well recognized as standard practice of risk allocation in joint space activities, where "each party assumes its own risks inherent in the cooperative activity" (WHOLLEY; MIRMINA, 2008, p. 6). Section 309 of the Space Act authorizes NASA to grant a waiver of claims on a reciprocal basis. Save for 
a few exceptions, both states parties to a bilateral framework agreement agree not to sue each other for any damage caused by the mutual activities. Apart from other more practical considerations, this solution serves to foster inter-state collaboration in the exploration of outer space.

\subsection{Dispute settlement systems accessible by both states and private entities}

Since this part of the article will primarily deal with different types of arbitration that are available to states and private parties to an outer space activity related dispute, a short introduction as to the generally accepted core principles of arbitration is warranted. To begin with, as already mentioned, arbitration is typically open to all - states, legal and natural persons, international organizations, etc. A key characteristic is the presumptive in many cases confidentiality of arbitration proceedings, which many consider to be essential to its appeal, while others find grounds to criticize it on that count. It is also typical for parties to be able to choose their arbitrators from a pool of experienced and impartial professionals (HERTZFELD; NELSON, 2011, p. 9). Traditionally, arbitration is perceived as more expeditious and cost-effective than litigation, which may, however, prove to not necessarily be the case. ${ }^{8}$

After this optimistic start, it is suitable to reflect on what does not work that well in arbitration. To begin with, the confidentiality that arbitration users are so fond of may not be looked upon so favorably by other stakeholders who are not parties to the dispute, but are indirectly affected by the outcome. The lack of publicity of arbitral awards ${ }^{9}$ also creates difficulty in establishing precedent and by virtue of that impedes the

\footnotetext{
${ }^{8}$ For an explanation on the increasing costs and delays in arbitration, see REDFERN; HUNTER, 2015, p. 34-37.

9 Save for ICSID and International Chamber of Commerce (ICC) decisions, which are usually disseminated to the public.
} 
achieving of a higher level of predictability, which is crucial to any system of dispute settlement.

Another disadvantage can be inferred from states' general unwillingness to submit confidential information to an arbitral tribunal, despite the non-public character of the proceedings (HERTZFELD; NELSON, 2011, p. 9). Finally, as arbitrators are not always required to provide parties with a written rationale, this frustrates the purpose of allowing a party to understand the reasons for the wrongful nature of its conduct and how to remedy it in the future. A view has been expressed that arbitration in space disputes is most viable for accidents in outer space involving two or more different states or companies headquartered in different states, where the damage suffered is enough to warrant the constitution of an international tribunal and where primary resolution through diplomatic negotiations is not possible (HERTZFELD; NELSON, 2011, p. 10).

Some of the existing dispute resolution mechanisms are considered below, which can be applied to deciding space-related matters. The sequence with which they are presented follows no particular order, save for transiting from methods dominated by states' participation through the, in this author's opinion, aurea mediocritas of the Permanent Court of Arbitration Optional Rules for Arbitration of Disputes Relating to Outer Space Activities [hereinafter PCA Space Arbitration Rules] and finally arriving to methods primarily concerned with the individual, such as the Convention for the Protection of Human Rights and Fundamental Freedoms [hereinafter ECHR Convention]. As a final preliminary note, commercial arbitration between private entities is possible under either the ICC Rules of Arbitration or the UNCITRAL Arbitration Rules - these rules however may not necessarily be adequate to address the specificity of disputes regarding outer space activities (WEBSTER, 2010). 


\subsubsection{The European Space Agency dispute resolution mechanism}

Although the European Space Agency [hereinafter ESA] is an intergovernmental organization that deals primarily with inter-state disputes, Article 25 of Annex I to the Convention for the Establishment of a European Space Agency [hereinafter the ESA Convention] stipulates for a second type of dispute resolution, i.e. arbitration for ESA contracts, hence its inclusion here and not in the previous category.

With respect to inter-state disputes, the ESA Convention of 1975 provides in art. 17(1) that in case the matter is not solved by or through ESA's Council of Ministers, either party may submit the dispute to arbitration, which is final and binding upon the parties. Article 17(2) of the ESA Convention allows states to choose the rules for the arbitration procedure, a right which if not exercised would subject the arbitration to the rules contained in Article 17.

The main disadvantage of this dispute resolution tool is, understandably, its limited scope - first, only between members of ESA, or between a member and ESA itself, and second, regarding only "the interpretation or application of this Convention or its Annexes" (ESA CONVENTION, 1975, art. 17[1]). Absence of any disputes under the ESA Convention may be attributed to the widespread adoption and use of crosswaivers of liability (BOHLMANN, 2013, p. 4), which were referred to in the previous segment.

Turning to disputes that arise under an ESA contract, they are, as noted above, subject to arbitration, after the parties have employed their 'best efforts' to resolve the dispute amicably (ESA, 2013, Clause 35[1]). The rules to govern such arbitration, absent agreement to the contrary, will be the International Chamber of Commerce Rules of Arbitration [hereinafter ICC Rules] (ESA, 2013, Clause 35[2]). To date, there are no records of any arbitration proceedings instituted between ESA and a private contractor 
(FARAND, 2011, p. 150), which is also assumed to be a consequence of the wide implementation of cross-waivers of liability (BOHLMANN, 2013, p. 7). This is significant, as roughly 85 percent the budget of ESA is spent on contracts with private entities from the space industry, whereby ESA's budget for 2013 was over 4 billion Euro (BOHLMANN, 2013, p. 6).

\subsubsection{PCA Space Arbitration Rules}

\subsubsection{Raison d'être of the PCA Space Arbitration Rules}

The substantial increase in the number and variety of actors involved in space activities - over 30 countries possessing space industries as opposed to the longstanding historical domination of the U.S. and the former USSR (GOH, 2007, p. 164), the relative relaxation of government control over space activities (GOH, 2007, p. 157) and the development of a variety of potential commercial uses of outer space has led to "the influx of a variety of non-state actors onto the stage of space law" (POCAR, 2012, p. 175). PCA Space Arbitration Rules were therefore created to address the lacuna in the dispute resolution framework which existed until then, whereby private entities had remained largely unrepresented (POCAR, 2012, p. 175).

\subsubsection{The main advantages}

As we see from the introduction of the PCA Space Arbitration Rules, they were based on the 2010 UNCITRAL Arbitration Rules with changes in order to "reflect the particular characteristics of disputes having an outer space component involving the use of outer space by States, international organizations and private entities" (PCA, 2011) Immediately apparent advantages include the discretion of disputing parties as to the selection of arbitrators and the procedural rules to be applied (VIIKARI, 2011, p. 242). 
Additionally, the PCA Space Arbitration Rules under art. 26 thereof provide for the possibility of the arbitral tribunal to order interim measures HOFMANN, 2014, p. 2). Furthermore, arts. 28 and 34 of the rules establish the confidential character of the hearings and the final award, which is particularly important for states, as space-related activities, even when primarily commercial in nature, almost invariably involve interests of technological advancements or national security, such as remote sensing imagery (GABRYNOWICZ, 2010, p. 6-7).

\subsubsection{Anything wrong with them?}

There are not a lot of disadvantages to this system of dispute settlement, which allows for both inter-state and investor-state arbitration. It has been suggested, however, that the PCA Space Arbitration Rules have a limited role to play as regards purely private disputes (VIIKARI, 2011, p. 243). More proper venues for this type of dispute may be found infra.

\subsubsection{Applicability of the ICC Rules to outer space disputes}

The main advantages associated with the ICC Rules of Arbitration of 2017 appear to be shared between most methods on international arbitration, in that they provide a neutral venue, flexibility for parties to choose the framework within the limits of which their dispute will be resolved, confidentiality of the proceedings and the final award, etc. One important additional benefit for the users of the ICC Rules of Arbitration provided by art. 1(2) is the supervisory functions exercised by the International Court of Arbitration to ensure quality of proceedings. Another positive remark relates to its popularity as a method of resolving disputes on outer space activities (RAVILLION, 2004, p. 2), which signifies the high degree of reliability it exhibits to arbitration users.

A typically cited drawback of the ICC Rules relates to the high fees imposed on the parties, which are based on a percentage of the amount in 
dispute (ICC RULES OF ARBITRATION, 2017, app. 3 - art. 3[b]; BOSTWICK, 1995, p. 33). This is significant as recovery in disputes relating to outer space activities usually involves a considerable monetary amount (HOUT, 2002, p. 15).

\subsubsection{ILA Draft Convention on Settlement of Outer Space Disputes [hereinafter ILA Draft Convention]}

The International Tribunal for Space Law is established under Article 37 of the 1984 ILA Draft Convention. One of its main advantages is the inclusion of both states and private entities as its potential users (COMMITTEE ON THE PEACEFUL USES OF OUTER SPACE LEGAL, 2001, p. 15). The ILA Draft Convention also envisages the possibility of conciliation preceding arbitration, whereby if parties agree to conciliation, under Article 21 they are bound to it until proceedings are terminated or until after the conciliators have sent their recommendations to the parties (SCHAEFER, 2001, p. 216-217).

There is also a wide scope of application, which includes "all activities in or with effects in outer space, if carried out by states or IGOs parties to the convention or nationals of contracting states or from the territory of such states" (LOTTA, 2011, p. 234), but states may opt out of some of the provisions of the Convention or limit its applicability to certain space activities under Article 1.2 of the ILA Draft Convention, which would in turn lead to undermining the harmonization of dispute resolution procedures (KURLEKAR, 2016, p. 393). Another perhaps not ideal solution was the inclusion of non-exclusive exercise of jurisdiction by the Tribunal, meaning that the parties could refer their disputes concurrently to the ICJ or an ad hoc arbitration (KURLEKAR, 2016, p. 393). 


\subsubsection{European Court of Human Rights [ECHR]}

The ECHR was established to adjudicate on alleged violations of human rights under the Convention for the Protection of Human Rights and Fundamental Freedoms [hereinafter ECHR Convention] by a state party to the convention with respect to any person within their jurisdiction (ECHR CONVENTION, 1950, art. 1).

Article 10 of the ECHR Convention, which protects the freedom of expression, has given rise to several cases involving space activities, relating most of all to either rejection of broadcasting licensing or denial of the right to install satellite dishes (ECHR, 2008).

\subsubsection{Multi-door courthouse system}

The multi-door courthouse system is based on the concept of a courthouse which provides all types of dispute resolution services under 'one roof', where the court assists the parties in choosing the best mechanism to solve their differences (GOH, 2007, p. 8). This model features a unique procedure of "screening" of disputes prior to determination as to the most suitable form of dispute settlement (GOH, 2007, p. 8). Such screening is done by experts who evaluate the best mode of dispute resolution through a thorough examination of the facts and taking into account the preference expressed by the parties (GOH, 2007, p. 292). The screening process ultimately should produce a comprehensive analysis of "cost, speed, requirement of confidentiality and the requirement of binding nature of the resolution" (KURLEKAR, 2016, p. 394).

Despite boasting significant advantages in terms of efficacy, the screening process has been dubbed by some authors to involve issues of transparency as to selection of screening experts as well as concerns regarding their rather substantial powers in determining the method of 
dispute resolution which might impact the final result (KURLEKAR, 2016, p. 394).

\subsubsection{International Space and Aviation Arbitration Court}

Created by the French Air and Space Law Society, the International Space and Aviation Arbitration Court is located in France and based upon French law and is aimed at the resolution of space-related disputes between international parties that are exclusively private entities (BOURELY, 1993, p. 144). The rules of the court envisage that it delivers a final and binding award for disputes referred to it.

In a typical fashion for arbitral tribunals, its proceedings and final award are strictly confidential. The rules also provide for the possibility of the arbitral tribunal to issue an interim award. The rules of the court similarly provide a list of specialized arbitrators sorted in categories depending on their respective field of expertise. As for costs, those represent a lump sum due for each day there is a hearing of the arbitral tribunal (VIIKARI, 2011, p. 238).

Despite being a commendable initiative, the relevance of this arbitration court is questionable as no cases are known to have been referred to it (VIIKARI, 2011, p. 239).

\section{Some conclusory remarks}

As I deliver my final thoughts, I would like to revisit the position I already took in the beginning of this article, namely that there is not and to reinforce this - should not be a 'one-size-fits-all' solution to any type of dispute settlement to begin with, but especially where highly complex and technically specialized issues arise as is the case with outer space activities. I consider that the variety of options currently open to states and private entities to resolve their disputes is a good indicator for future development and I also find that businesses will eventually 'root out' ineffective legal 
regimes and improve the ones that work so that they provide even better service.

I do find that investor-state dispute resolution is in need of greater assurances with respect to execution of foreign arbitral awards and I am certain the day will come at some point where a balance is stricken between sovereign immunity and creating a level-playing field for foreign enterprises, which should by itself incentivize investments in countries that respect arbitral awards despite the outcome.

In terms of inter-state dispute resolution when outer space activities are concerned, it is no surprise that states prefer to settle their differences through negotiations and consultations, rather than arbitration. States are generally reluctant to submit to a binding mechanism of dispute settlement, especially in advance of any such dispute arising (BÖCKSTIEGEL, 1993, p. 137), as this is viewed as constraining states' exercise of sovereignty (WILLIAMS, 1996, p. 63).

While on the topic of inter-state dispute resolution, suggestions have been made for the creation of a new Space Law Court or Tribunal, modelled after ITLOS for example, wherein this new Space Court should be able to provide Advisory Opinions like the ICJ, so as to enhance predictability in the resolution of disputes relating to outer space activities (ILA, 1998, p. 248). There is another important consideration whether a creation of a specialized court or tribunal for space activities is warranted, and namely will it have enough cases to justify its existence, at least presently and in the foreseeable future?

Assuming, arguendo, that there is such a potential, many of those disputes will quite possibly deal not only with outer space activities and their legal implications, but a whole plethora of legal issues that may as well be decided by a court that does not necessarily possess a specialized competence in the field of space law. That begs the question - how are we to determine which cases will be covered by the jurisdictional scope of such a 
court or tribunal? Perhaps this difficulty could be circumvented by attaching this court or tribunal to a convention that deals with a variety of spacerelated issues, in a manner akin to the International Tribunal for the Law of the Sea [hereinafter ITLOS] and the 1982 United Nations Convention on the Law of the Sea [hereinafter UNCLOS].

Upon identifying the best mechanisms for dispute settlement for outer space activities, representation of as wide a variety of stakeholders' interests as possible is crucial, especially considering the growing importance of the space industry (MARSHALL, 2017). This perspective shows one of the major drawbacks of arbitration, which as a principle focuses exclusively on the dispute between the parties before it. The international regime on the law of the sea embodied in UNCLOS may again prove to provide a good solution by virtue of Article 187, whereby in specific circumstances even private entities may appear before ITLOS.

Ultimately, is there any type of dispute settlement which we can point to as being the best? Arbitration for its binding effect and alleged impartiality and finality? This article has already shown various flaws of arbitration, most notably the lack of reliability as to whether the losing state will suffer execution against its assets due to a defense based on sovereign immunity. Another imperfection, as discussed in the preceding paragraph involves the lack of representation of vast swaths of stakeholders. Should we then turn to adjudication?

The ICJ may be a good venue for states to settle their disputes, but at present it is inaccessible to private parties. ICSID seems to be on the right track to providing a successful solution to states and investors seeking protection, but such success is contingent to a huge degree on the willingness of states to sacrifice their sovereign immunity when dealing with private entities, a prospect which seems distant at present. If a winner has to be picked, I would probably go with the PCA Space Arbitration Rules if at least one of the parties was a private entity, whereas if both parties to 
the dispute are states, negotiations and consultations remain the best first and hopefully last choice of dispute settlement in the field of outer space activities.

\section{References}

BÖCKSTIEGEL, Karl-Heinz. Settlement of Disputes Regarding Space Activities. Journal of Space Law, v. 21, n. 1, pp. 1-10, 1993.

. Arbitration of Disputes Regarding Space Activities. In: IISL. Proceedings of the 36th Colloquium on the Law of Outer Space. Oct. 16-22, 1993.

BOHLMANN, Ulrike M. Disputing with ESA, v. 14, 64th International Astronautical Congress. Beijing (China), Sept. 23-27, 2013.

BOSTWICK, Phillip. Going Private with the Judicial System: making creative use of ADR procedures to resolve commercial space disputes. Journal of Space Law, v. 23, n. 1 pp. 19-42, 1995.

BOURELY, Michel G. Creating an International Space and Aviation Arbitration Court. Proc. on L. Outer Space, n. 36. pp. 144 et seq. 1993.

BRISIBE, Tare. A Normative System For Outer Space Activities In The Next Half Century. 5th Nandasiri Jasentuliyana Keynote Lecture, 64th International Astronautical Congress, Beijing, China, International Astronautical Federation, 2013.

BURKE, Joseph. Convention on International Liability for Damage Caused by Space Objects: Definition and Determination of Damages After the Cosmos 954 Incident. Fordham International Law Journal, v. 8, n. 2, pp. 263 et seq., 1984.

CHENG, Chia-Jui. International Arbitration System as Mechanism for the Settlement of Disputes Arising in Relation to Space Commercialization. Singapore J. Intl \& Comp. L., n. 5, pp. 167 et seq., 2001.

COMMITTEE ON THE PEACEFUL USES OF OUTER SPACE LEGAL. Information on the activities of international organizations relating to space law - Doc. A/AC.105/C.2/L.223. Fortieth session, Vienna, Apr. 2-12, 2001.

DRAFT Convention on the Settlement of Space Law Disputes, J. Space Law, Space L., v. 12, pp. 136 et seq. 1984 .

ECHR. Convention for the Protection of Human Rights and Fundamental Freedoms. 1950.

Case Of Khurshid Mustafa and Tarzibachi v. Sweden (Application no. 23883/06). Judgment. Strasbourg. Dec. 16, 2008.

ESA. Convention for the establishment of a European Space Agency: CSE/CS(73)19, rev.7. May 30, 1975.

General Clauses and Conditions for ESA Contracts: Regulations Of The European Space Agency - ESA/REG/002. Rev. 1. Paris, Feb. 7, 2013.

GABRYNOWICZ, Joanne Irene. Remote Sensing and Potential Optional Rules for Arbitration of Disputes Relating to Outer Space. Advisory Group Discussion Paper, 2010 . 
GOROVE, Stephen. Dispute Settlement in the Liability Convention. In: BÖCKSTIEGEL, K.-H. (ed.). Settlement of Space Law Disputes: the present state of the law and perspectives of further development - Proceedings of an International Colloquium, Munich, Sep. 13-14 1979. München: Heymann, 1980.

FARAND, Andre. The European Space Agency's Experience with Mechanisms for the Settlement of Disputes, Arbitration in Air, Space and Telecommunications Law. Papers emanating from the Third PCA International Law Seminar, pp. 145-156, 2001.

FOSTER. The Convention on International Liability for Damage Caused by Space Objects. Can. Yearbook Int'l L. n. 10, pp. 137 et seq., 1972.

GOH, Gerardine Meishan. Dispute Settlement in International Space Law: A MultiDoor Courthouse for Outer Space. Leiden: Martinus Nijhoff, 2007.

HERTZFELD, Henry; NELSON, Timothy. Binding Arbitration as an Effective Means of Dispute Settlement for Accidents in Outer Space. E7. 56th IISL Colloquium on the Law of Outer Space, IAC-13, 2011.

HOFMANN, Mahulen. Space Activities In The Jurisprudence Of International Dispute Settlement Institutions. 57th IISL Colloquium On The Law Of Outer Space (E7), Joint IAF/IISL Session on the Legal Framework for Cooperative Space Activities, 65th International Astronautical Congress, 2014.

HOUT, Tjaco van den. Introduction. In: THE INTERNATIONAL BUREAU OF THE PCA (ed.). Arbitration in Air, Space and Telecommunications Law: enforcing regulatory measures, Papers emanating from the Third PCA International Law Seminar, Feb. 23, 2001. The Hague, London, New York: Kluwer Law International, 2002.

ICC. International Chamber of Commerce Rules of Arbitration - Appendix 3, 2017.

ICJ. Interpretation of the Peace Treaties with Bulgaria, Hungary and Romania. Advisory Opinion of 30 March 1950 (fi rst phase), 1950 ICJ Rep. 65.

Chambers and Committees. The Hague, w/d. Available at: < http://www.icj-cij.org/en/chambers-and-committees>. Last visited on 10 May 2018.

Case concerning the Barcelona Traction Light and Power Company Limited (Belgium v. Spain) - Second Phase, Judgment, I.C.J. Reports 1970.

ICSID - International Center for Settlement of Investment Disputes. World Bank Group Database of ICSID Member States. Available at: $<$ https://icsid.worldbank.org/en/Pages/about/Database-of-Member-States.aspx>. Last visited on 10 May 2018.

Convention on the Settlement of Investment Disputes between States and Nationals of Other States. 1965.

ICSID Model Clauses: Doc. ICSID 5/Rev.2. Feb.1, 1993.

ILA. Report of the 68th Conference of the International Law Association. Taipei, Taiwan (Republic of China), May 24-30 1998

ILC. ILC Draft Articles on Diplomatic Protection with commentaries, Yearbook of the International Law Commission, vol. II, Part Two, 58 ${ }^{\text {th }}$ Session, 2006.

KERREST, Armel. Dispute Resolution Mechanism for Damage Caused by Space Objects. IISLECSL Symposium, UNCOPUOS Legal sub-committee meeting, Vienna, 1 April 2001. $I n$ : ISIL. Proceedings of the 44th Colloquium on the Law of Outer Space, Toulouse, Oct. 1-5 2001. 
KURLEKAR, Arthad. Space - The Final Frontier: Analysing Challenges of Dispute Resolution Relating to Outer Space. Journal of International Arbitration. v. 33, n. 4, pp. 379-416, 2016.

LEYS, Davi. Diplomatic Protection and Individual Rights: A Complementary Approach. Harvard International Law Journal Online, v. 57, jan. 2016

MARSHALL, Will. Space technology is improving our lives and making the world a better place: here's how. World Economic Forum, 2017. Available at: $<$ https://www.weforum.org/agenda/2017/07/using-space-to-help-global-development/>. Last visited on 10 May 2018.

NEW YORK CONVENTION GUIDE, New State Party to the New York Convention, w/d. Available at: $<$ http://newyorkconvention 1958. org/index.php?lvl=cmspage\&pageid=7\&id_news=1000\&opa c_view=-1>. Last visited on 10 May 2018.

PCA. Permanent Court of Arbitration Optional Rules for Arbitration of Disputes Relating to Outer Space Activities. Dec. 6, 2011.

PCIJ. Mavrommatis Palestine Concessions (Greece v. Great Britain). Judgment of 30 August 1924, 1924 PCIJ (Ser. A) No. 2.

POCAR, Fausto. An Introduction to the PCA's Optional Rules for Arbitration of Disputes Relating to outer Space Activities. J. Space L., n. 38. pp. 171 et seq., 2012.

RAVILLION, Laurence. Space Law and Mechanisms for Dispute Settlement. ECSL News - n. 28, Dec. 2004.

REDFERN; HUNTER. International Arbitration. $6^{\text {th }}$ edition. Sep 2015.

SAUNDERS, Matthew; SALOMON, Claudia. Enforcement of Arbitral Awards Against States and State Entities, Arbitration International, v. 23, n. 3, LCIA, 2007, pp. 467476.

SCHAEFER, Jan K. Pre-Arbitration Procedures, Arbitration in Air, Space and Telecommunications Law. Papers emanating from the Third PCA International Law Seminar, pp. 211-233, 2001.

SUPANCANA, Ida Bagus Rahmadi. The International Regulatory Regime Governing the Utilization of Earth-Orbits. Leiden: Rijksuniversiteit te Leiden, 1998.

TRONCHETTI, Fabio. Bringing space law in the 21st century: the Permanent Court of Arbitration adopts Optional Rules for Arbitration of Disputes Relating to Outer Space Activities. 56th IISL Colloquium on the Law of Outer Space (E7), Settlement of SpaceRelated Disputes (2), 64th International Astronautical Congress, 2013.

UNITED NATIONS. Unites Nations General Assembly. Res. 1721 (XVI)A: International Co-operation in the Peaceful Uses of Outer Space. 1961.

Unites Nations General Assembly. Res. 1802 Preamble (XVII): International Co-operation in the Peaceful Uses of Outer Space. 1962.

Unites Nations General Assembly. Res. 1962 (XVIII): Declaration of Legal Principles Governing the Activities of States in the Exploration and Use of Outer Space. 1963.

Statute of the International Court of Justice. 1945.

Unites Nations Charter. 1945. 
Treaty on Principles Governing the Activities of States in the Exploration and Use of Outer Space, including the Moon and Other Celestial Bodies. 1967.

Objects. 1972.

Convention on International Liability for Damage Caused by Space

VIIKARI, Lotta. Towards More Effective Settlement of Disputes in the Space Sector. Lapland Law Review. n. 1, pp. 226-251, 2011.

WEBSTER, Thomas H. Handbook of UNCITRAL Arbitration. 4th edition. London, Sweet \& Maxwell, 2010.

WHOLLEY, Michael C.; MIRMINA, Steven A. Bilateral legal framework agreements governing international cooperation in outer space, International Institute of Space Law, 51st International Colloquium on the Law of Outer Space at 7. Glasgow (Scotland), 2008.

WILLIAMS, Sylvia-Maureen. Dispute Settlement and Space Activities: a new framework required? In: IISL. Proceedings of the 39th Colloquium on the Law of Outer Space. Beijing, Oct. 7-11 1996.

WTO. WTO Dispute settlement. Geneva, w/d. Available at: $<$ https://www.wto.org/english/tratop_e/dispu_e/dispu_e.htm>. Last visited on 10 May 2018.

Artigo recebido em: 14/05/2019.

Aceito para publicação em: 19/11/2019. 